\title{
Investment Awards Based on International Law in Conflict with European Union Law - The Special Case of the Micula Award*
}

\author{
BY TAMÁs KendE**
}

\begin{abstract}
CEE states, following their accession into the European Union in 2004 and 2007, have been inundated with numerous lawsuits by foreign and, in many cases, European investors in front of international tribunals. Some of these cases involved state aid provided by member states to investors and when these state aid measures were revoked, based on decision of the European institutions, the aggrieved investors turned to both EU instances and international arbitrations. These EU decisions forced CEE states to take certain measures, often by curtailing contractual rights awarded by CEE states to international or Western European investors. The investors tried to invalidate the European Commissions' decisions in front of the EU Court of First Instance/General Court and subsequently in the Court of Justice. When these initiatives failed, the facts of these cases were subsequently represented by many of these investors in international fora, such as the International Centre for Settlement Investment Disputes (ICSID), or arbitrations organised under the UNCITRAL rules.

Keywords: investors, international tribunals, International Centre for Settlement Investment Disputes, UNCITRAL, Micula case
\end{abstract}

\section{INTRODUCTION}

CEE states, following their accession into the European Union in 2004 and 2007, have been inundated with numerous lawsuits by foreign and, in many cases, European investors in front of international tribunals. ${ }^{1}$ Around 77 cases (up to mid 2014) were brought against CEE states which included 18 cases against the Czech Republic, 15 cases against Poland and 10 cases each against Hungary and Slovakia. ${ }^{2}$ However, only seven lawsuits were initiated against Western European states such as Germany, Spain, Belgium, Portugal, United Kingdom, Finland, France, Ireland, Italy, Luxembourg, Netherlands, Denmark, Sweden and Austria. ${ }^{3}$ Sixty-five percent (50 cases) of all disputes against the CEE states were initiated by European investors based on intra-EU BITs. ${ }^{4}$ The majority of international investment arbitrations were initiated against capital importing CEE states by investors from (or investors established in) capital exporting Western European states.

* The author published an earlier version of this study reflecting his opinion in the ELTE Law Journal 2015/1 under the title „Arbitral Awards Classified as State Aid under European Union Law”.

** Associate professor, ELTE Law School. E-mail: tkende@ajk.elte.hu

${ }^{1}$ Investor to State Dispute Settlement (ISDS) - Some facts and figures page 5 and 6 European Commission DG Trade at <http://trade.ec.europa.eu/doclib/docs/2015/january/tradoc_153046.pdf $>$ accessed 23 May 2016, and Recent Trends in IIAs and ISDS in $<$ http://unctad.org/en/Publications Library/webdiaepcb2015d1_en.pdf $>$ 7, accessed 23 May 2016.

2 Investor to State Dispute Settlement (ISDS) - Some facts and figures page 5 and 6 European Commission DG Trade, 7.

3 Investor to State Dispute Settlement (ISDS) - Some facts and figures page 5 and 6 European Commission DG Trade, 7.

${ }^{4}$ Olivet (2013) 3. 
Many of these cases originated from the adjustment to the EU single market prior to EU accession. However, in some cases, the basis of the complaint by investors in these international arbitrations were not measures adopted during accession but, rather, were based on EU norms or decisions issued subsequent to CEE states' accessions. ${ }^{5}$ Some of these cases involved state aid provided by member states to investors and when these state aid measures were revoked, based on decision of the European institutions, the aggrieved investors turned to both EU instances and international arbitrations. These EU decisions forced CEE states to take certain measures, often by curtailing contractual rights awarded by CEE states to international or Western European investors. These investors realised that CEE states' measures were mostly implementing European norms and decisions of the European Commission (following lobbying in vain against implementation) and thus tried to invalidate the European Commissions' decisions in front of the EU Court of First Instance/General Court and subsequently in the Court of Justice. When these initiatives failed, the facts of these cases were subsequently represented by many of these investors in international fora, such as the International Centre for Settlement Investment Disputes (ICSID), or arbitrations organised under the UNCITRAL rules.

The analysis of this problem will form the foundation of this paper.

\section{STATE AID UNDER EUROPEAN UNION LAW}

The problem with State aid is that certain government entities support industries or private companies by spending public funds and, therefore giving them an unfair advantage over industries in the similar sector of industry in other EU Member States. ${ }^{6}$ The European Commission is in charge of ensuring and enforcing compliance with its State aid rules. ${ }^{7}$

\subsection{What is state aid?}

According to Article 107 of the Treaty of the Functioning of the European Union (TFEU), state aid is any aid granted by a Member State or through State resources in any form whatsoever which distorts or threatens to distort competition by favouring certain undertakings. ${ }^{8}$ In order for an award to be considered "State aid," there are four conditions that must be met: The measure must confer a selective economic advantage upon an undertaking; the measure must be imputable to the State and financed through State resources; the measure distorts or threatens to distort competition; and the measure must have the potential to affect trade between Member States. ${ }^{9}$ The TFEU uses these factors for

5 Olivet (2013) 4.

${ }^{6}$ See at $<$ http://ec.europa.eu/competition/consumers/government_aid_en.html $>$ accessed 23 May 2016. 2016.

${ }^{7}$ See at $<$ http://ec.europa.eu/competition/state_aid/overview/index_en.html $>$ accessed 23 May

${ }^{8}$ EC: Communication from the Commission: Draft Commission Notice on the notion of State Aid pursuant to Article 107(1) of TFEU.

${ }^{9}$ See at $<$ http://ec.europa.eu/competition/state_aid/overview/index_en.html $>$ accessed 23 May 2016. 
the interpretation of when State aid is or may be declared compatible. ${ }^{10}$ The European Commission has been given great leniency to make normative declarations that certain types or categories of aid are compatible. ${ }^{11}$

\subsection{What Constitutes illegal state aid?}

Member States are generally required to notify the Commission in advance (ex ante) of any plans to grant state aid, except in cases covered by the conditions set out in block exemption regulations. ${ }^{12}$ Aid is deemed incompatible if the notification ex ante does not take place or if the aid does not conform with the conditions set out in the block exemption regulation. If notification has taken place but the notified aid has been cleared with conditions and such conditions were not met then the aid is also considered incompatible and, therefore, illegal.

\subsection{Can a court judgement or an arbitral award constitute illegal state aid?}

It is arguable whether decisions of judges in ordinary courts or in arbitral tribunals, created with the consent of Member States, are decisions "attributable" to such states within the meaning of Article 2 of the Draft articles on Responsibility of States for Internationally Wrongful Acts ${ }^{13}$ of the International Law Commission. This "attributability" seems much broader than imputability in the EU state aid sense, as court decisions are clearly attributable to a state under international law within Article 4 of the Draft Articles, even if the government actively fought those decisions. ${ }^{14}$

In the opinion of the author, it would be easy to attribute or impute the decisions of an arbitration tribunal to the state, even if it was not naming more than a mere one third of the arbitrators to the tribunal. Arguably, by simply accepting the rules of selections of the arbitrators, the state has agreed to a composition of the arbitral tribunal, even if it has not agreed to specific individuals to be nominated as arbitrators.

In summary, there are grounds to argue that, under EU law, save for the exceptions discussed below, an investment award itself, and subsequently, the enforcement of an

\footnotetext{
10 See at $<$ http://ec.europa.eu/competition/state_aid/overview/index_en.html $>$ accessed 23 May 2016.

11 Commission Regulation (EU) No 651/2014 of 17 June 2014 declaring certain categories of aid compatible with the internal market in application of Articles 107 and 108 of the Treaty Text with EEA relevance OJ L 187, 26.6.2014, 1-78 at http://eur-lex.europa.eu/legal-content/EN/TXT/HTML/? uri=OJ:L:2014:187:FULL\&from=EN accessed 23 May 2016.

12 There are also types of aid which are declared compatible by Article 107(2) or may be compatible under Article 107 (3) TFEU.

13 Draft articles on Responsibility of States for Internationally Wrongful Acts, with commentaries 2001 Text adopted by the International Law Commission at its fifty-third session, in 2001, and submitted to the General Assembly as a part of the Commission's report covering the work of that session (A/56/10. in the Yearbook of the International Law Commission, 2001, vol. II, Part Two, as corrected.)

141 . The conduct of any State organ shall be considered an act of that State under international law, whether the organ exercises legislative, executive, judicial or any other functions, whatever position it holds in the organization of the State, and whatever its character as an organ of the central Government or of a territorial unit of the State.
} 
investment award, does not generally constitute illegal State aid under Article 107 TFEU because the payment of compensation is involuntary. This argument is seemingly wellsupported by authorities under EU law, but also weak because the EU member states themselves had agreed to the ISDS procedures and, therefore, the decisions of the tribunals are as attributable (imputable) to the member states as are the decisions of their ordinary courts.

Tietje and Wackernagel think that decisions by arbitrations are generally not imputable in the state aid law sense but concede that when an international arbitral procedure is aimed at restoring state aid that an EU Commission decision confirmed by an EU Court judgment declared illegal, the award in such an international arbitral procedure may be considered as one reinstating illegal State aid, “.... enforcement of an intra-EU investment award does not, as a general rule, constitute illegal state aid under Article 107 of the ...TFEU.... However .... enforcement can constitute illegal state aid if the measure found to violate the investment agreement consisted of repealing a legal regime that itself constituted illegal state aid..." 15 They agree to this exception to the rule under EU law.

\subsection{EU state aid cases and international arbitrations}

The EU's position and the arguments the Commission has made relating to the unenforceability of international awards contrary to EU law are both readily apparent through a number of ICSID cases where the Commission has intervened as amicus curiae. ${ }^{16}$ In the Electrabel, ${ }^{17} \mathrm{AES},{ }^{18} \mathrm{EDFI}^{19}$ and Micula $^{20}$ cases the Commission intervened as amicus curiae and argued that EU law should prevail if it conflicts with the decisions of international tribunals.

Table 1. The four cases

\begin{tabular}{|l|l|l|l|l|l|l|}
\hline Case & Investor & State & Claim & Legal title & Decision & $\begin{array}{l}\text { Reaction } \\
\text { to amicus }\end{array}$ \\
\hline Electrabel & Belgian & Hungary & $\begin{array}{l}\text { Termination } \\
\text { of PPA is } \\
\text { expropriation }\end{array}$ & $\begin{array}{l}\text { ECT, } \\
\text { ICSID }\end{array}$ & $\begin{array}{l}\text { Partially } \\
\text { rejected, } \\
\text { one issue } \\
\text { to be decided } \\
\text { in 2016 }\end{array}$ & $\begin{array}{l}\text { Dealt with } \\
\text { EU amicus }\end{array}$ \\
\hline AES & UK & Hungary & $\begin{array}{l}\text { Termination } \\
\text { of PPA, } \\
\text { regulatory caps } \\
\text { constitute } \\
\text { expropriation }\end{array}$ & $\begin{array}{l}\text { ECT, } \\
\text { ICSID }\end{array}$ & Claim rejected & $\begin{array}{l}\text { Did not deal } \\
\text { with amicus }\end{array}$ \\
\hline
\end{tabular}

15 Tietje (2014) 3.

16 See about this: González-Bueno (2015).

17 Electrabel S.A. v. Hungary (ICSID Case ARB 07/19).

18 AES Summit Generation Limited and AES-Tisza Erömü Kft.v. Hungary (ICSID Case ARB $07 / 22)$.

19 EDF International v. Hungary (PCA Case 2009-13).

${ }^{20}$ Ioan Micula, Viorel Micula and others v. Romania (ICSID Case No. ARB/05/20). 


\begin{tabular}{|l|l|l|l|l|l|l|}
\hline Case & Investor & State & Claim & Legal title & Decision & $\begin{array}{l}\text { Reaction } \\
\text { to amicus }\end{array}$ \\
\hline EDFI & French & Hungary & $\begin{array}{l}\text { Regulatory } \\
\text { expropriation }\end{array}$ & $\begin{array}{l}\text { ECT, } \\
\text { UNCITRAL }\end{array}$ & $\begin{array}{l}\text { laim } \\
\text { accepted, } \\
\text { set-aside } \\
\text { action } \\
\text { rejected }{ }^{21}\end{array}$ & $\begin{array}{l}\text { Rejected } \\
\text { the arguments } \\
\text { in the amicus }\end{array}$ \\
\hline Micula & Swedish & Romania & $\begin{array}{l}\text { Withdrawal } \\
\text { of investment aid } \\
\text { violates FET }\end{array}$ & BIT, ICSID & $\begin{array}{l}\text { Claim } \\
\text { accepted, } \\
\text { annulment } \\
\text { action rejected }\end{array}$ & $\begin{array}{l}\text { Rejected } \\
\text { the arguments } \\
\text { in the amicus }\end{array}$ \\
\hline
\end{tabular}

The European Commission made three separate arguments as to why EU law should prevail in these conflicts.

\subsubsection{The Supremacy Argument}

In Electrabel and AES, the Commission partially rested its position on the argument that EU law takes supremacy over other international obligations of the Member States. According to the Commission's submission in these cases, EU law shall reign supreme if there is any material contradiction between the ECT and EU law. ${ }^{22}$ This specific argument is also rooted, according to the Commission, on the fact that the "[EU] was the driving force behind the adoption of the Energy Charter of 17 December 1991, and 'played a key role in negotiating the subsequent [ECT]." ${ }^{23}$

\subsubsection{The Lex Posterior Argument}

In Electrabel, AES, and Micula, the European Commission utilised the lex posterior argument revolving around the application of Article 16 of the ECT, which states that "where two or more Contracting Parties have entered into a prior international agreement... nothing in Part III or V of this Treaty shall be construed to derogate from any provision of such terms of the other agreement." ${ }^{24}$ With response to this, the Commission argued that the Article in question "applies only to the extent that the ECT is compatible with the Acts of Accession (and thus with EU law)." ${ }^{25}$ And moreover, all Member States had already agreed in 2004 "not to apply the conflict rule contained in Article 16 ECT, but the general supremacy rule of EC law." 26 In essence, the individual Member States have assented to the primacy of EU rules over prior contractual commitments then so too should the investors from those states.

${ }^{21}$ See at http://www.italaw.com/sites/default/files/case-documents/italaw4467.pdf accessed 23 May 2016.

22 Electrabel S.A. v. Republic of Hungary, ICSID Case No. ARB/07/19, Decision on Jurisdiction, Applicable Law and Liability Part IV-34, section 4.109 (November 30, 2012).

${ }^{23}$ Electrabel, Part IV - 31, section 4.99.

24 Energy Charter Treaty, December 17, 1994, 2080 UNTS 95.

25 Electrabel, Part IV-34, section 4.109.

26 Electrabel, Part IV-34, section 4.109. 


\subsubsection{The Circularity Argument}

The Commission utilised a final argument in all four cases as an amicus curiae to convince the arbitral tribunal not to rule in favour of the investors was so to put it the "circularity argument". This argument states that foreign arbitral awards are to be treated in some cases as decisions granting state aid under domestic law. Thus, the circularity argument thwarts application of foreign arbitral awards and, inter alia, Article 54 (1) of the ICSID Convention, by stating that, if a foreign award granting damages would reinstate state aid if it was implemented by a Member State as a judgement by its domestic courts, the foreign arbitral award itself would constitute state aid and would not be enforceable since it would be have been made in contradiction to EU law. ${ }^{27}$

The Micula case is the only one that the investor has finally won and the EU Member State has conclusively lost, shows how the circularity argument works in practice.

\section{THE MICULA CASE AND QUESTIONS OF ENFORCEMENT}

In Micula, two Swedish brothers and three Romanian food production businesses initiated a claim at ICSID based on the Romania-Sweden Bilateral Investment Treaty (BIT) after Romania cut incentives provided to investments of the Micula brothers that Romania claimed were in conflict with EU state aid law. ${ }^{28}$ The Swedish brothers set up a business with the belief that the tax incentives would be effective for a decade. ${ }^{29}$ Those incentives were later revoked because Romania claimed that this was in conformity with EU law. ${ }^{30}$

The European Commission intervened in the ICSID procedure. In its submission the Commission put forth that "any award requiring Romania to re-establish investment schemes which have been found incompatible with the internal market during accession negotiations, is subject to EU State aid rules" and "[t]he execution of such award thus cannot take place if it would contradict the rules of EU State aid policy." 31

The ICSID tribunal however, rejected this argument raised by the Commission on the basis that "it is not desirable to embark on predictions as to the possible conduct of various persons and authorities after the Award has been rendered, especially but not exclusively when it comes to enforcement matters. It is thus inappropriate for the Tribunal to base its decisions in this case on matters of EU law that may come to apply after the Award has been rendered. It will thus not address the Parties' and the Commission's arguments on enforceability of the Award." 32 As a result, the court accepted the brothers' claim and ordered Romania on December 11, 2013 to pay damages for failing to ensure a fair and equitable treatment of claimants' investments and thereby violating the Romania-Sweden BIT. $^{33}$

27 Electrabel, Part V-6, section 5.19.

28 See Global Investment Protection AG: Interference of the European Commission in the enforcement of arbitration awards: The Micula Case, 1.

${ }^{29}$ Global Investment Protection AG: Interference of the European Commission in the enforcement of arbitration awards: The Micula Case, 1.

30 Global Investment Protection AG: Interference of the European Commission in the enforcement of arbitration awards: The Micula Case, 1.

31 Micula at section 335.

32 Micula at section 342.

33 See EC Implementation of Arbitral Award Micula v. Romania (2013). 
After the ICSID decision granting compensation to the Micula brothers for Romania's breach of a BIT, the Commission has taken several steps to reverse the adverse ICSID decision and to block enforcement of the decision in Romania and outside the European Union.

\subsection{Steps to annul the ICSID decision of December 11, 2013}

On April 9, 2014, Romania, with the full backing of the EU Commission that filed an amicus curiae submission on January 9, 2015, filed an application with ICSID to annul the Award and requested a stay of enforcement of the Award, based, in part, on the argument that Romania's payment of the Award would violate European law. On April 18 2014, the Secretary-General of ICSID implemented in place a provisional stay. On August 7, 2014, an ICSID ad hoc committee conditioned the continuation of the stay on Romania's ability to file a letter with the ICSID Secretary-General within 30 days, "commit[ing] itself subject to no conditions whatsoever (including those related to E[uropean] law or decisions) to effect the full payment of its pecuniary obligation imposed by the Award..." 34 Romania failed to file the assurance and in a letter dated September 15, 2014, the ICSID confirmed that the stay on enforcement of the Award was "automatically revoked" as of September 7, 2014. ${ }^{35}$ During the annulment procedure, mainly due to the EU Commission's investigation into the legality of the Award, Romania passed a domestic legislative act, ${ }^{36}$ which suspended all of the enforcement actions initiated by the Micula brothers, as of March 9, 2015. According to Romania, this was to reconcile the two competing international obligations under the ICSID Convention and EU law and so the outstanding amount due under the Award in an escrow account for the benefit of Claimants, to be released to them if it was permitted by the EC in its forthcoming decision.

According to Romania, the Applicant had to recover the amounts paid under the Award or face infringement proceedings before the ECJ as the Final Decision had been rendered and this placed Romania in an impossible predicament of conflicting international obligations. Romania also stated that the Tribunal dodged the decision whether the enforcement of the ICSID Award would constitute unlawful state aid and what Romania can do in the face of conflicting international treaty obligations and the EU law requirements, stemming from the Member State status. The EU Commission itself clearly stated in its submission that the enforcement of the Award would constitute unlawful state aid and a recovery decision would have to be adopted. This was carried out before the annulment committee arrived at its decision, when the EU Commission adopted the recovery decision on March 30, 2015.

${ }^{34}$ Ioan Micula Et Al., Petitioners Against The Government Of Romania, Respondent.15 Misc. 107 (Part I) Opinion \& OrderUsdcSdny Document Electronically Filed Doc \#: Date Filed: 8/5/201 5 Micula Et Al V. The Government Of Romania Doc. 66 Dockets.Justia.Com United States District Court Southern District Of New York Lorna G. Schofield, District Judge, 3.

35 Ioan Micula Et Al., Petitioners Against The Government Of Romania, Respondent.15 Misc. 107 (Part I) Opinion \& OrderUsdcSdny Document Electronically Filed Doc \#: Date Filed: 8/5/201 5 Micula Et Al V. The Government Of Romania Doc. 66 Dockets.Justia.Com United States District Court Southern District Of New York Lorna G. Schofield, District Judge: Page 3.

${ }^{36}$ Law No. 20/2015. 
The EU Commission as amicus curiae contended that the Award must be annulled on the basis of three main defects: the Tribunal failed to apply the applicable law; the Tribunal failed to address the question of enforceability of the Award and the Tribunal exercised a jurisdiction that it did not have. The first two arguments were raised by Romania but the lack of jurisdiction of the Tribunal was an additional argument set forth by the EU Commission.

Regarding to the failure to apply EU law, the Commission argued that the Tribunal not just ignored the application of the relevant EU law but it also "manifestly misinterpreted and misapplied EU State aid law provisions, the Europe Agreement and Romania's domestic law" as well as it failed to address the conflict of treaties that was inherent in the underlying dispute. ${ }^{37}$ The latter was the most important argument where the Commission argued that "the Tribunal failed to address the conflict between Romania's obligations under the BIT and under the State aid provisions of the Europe Agreement. The Tribunal's reading of the Europe Agreement was selective to avoid any conflict and to justify the "quasi exclusive" application of the BIT." Moreover, the "Tribunal did not take into account related provisions of the Europe Agreement (Articles 64, 69 and 70), which provide that one of the Agreement's goals is to bring Romania's State aid legislation in line with that of the EU. If the Tribunal had done so, it would have concluded that there was a conflict of international obligations, or would have had to interpret the BIT in a manner so as to avoid the conflict. By failing to do either, the Tribunal manifestly exceeded its powers and failed to state the reasons upon which the Award was based." 38

The Commission also cited Article 59(1) of the Vienna Convention on the Law of the Treaties (VCTL) according to which the Sweden-Romania BIT should have been considered to be implicitly terminated by the parties with Romania's accession to the EU or at least the fact of the accession should have rendered the VCTL provisions conflicting with the TFEU inapplicable. With regard to Tribunal's jurisdiction was assumed under these inapplicable Articles 7 and 10, "the Tribunal should have declined jurisdiction because the BIT does not cover disputes involving questions of State aid, as this is a matter under the exclusive competence of the EU. Consequently, the Tribunal manifestly exceeded its powers under Article 52(1)(b) of the ICSID Convention." 39

The application for annulment by Romania was ultimately rejected by the ad hoc committee in a decision adopted February 26, 2016. ${ }^{40}$ The committee held that the grounds for annulment cited by Romania were unfounded and the Tribunal properly addressed all relevant issues of the case, including taking a position that the international contra EU law conflict need not to be addressed. The Committee accepted that the Tribunal simply decided that the enforcement issue was not necessary to the Tribunal's decision and that matters of EU law would only be relevant at the post-award phase. ${ }^{41}$

37 Law No. 20/2015 para. 310.

38 Law No. 20/2015, 317.

39 Law No. 20/2015, 334.

40 Ioan Micula, Viorel Micula and others v. Romania (ICSID Case No. ARB/05/20) Decision on annulment issued by the ad hoc Committee on February 26, 2016.

${ }^{41}$ Ioan Micula, Viorel Micula and others v. Romania, 234. 


\subsection{The EU Commission's steps to block enforcement of the decision in Romania}

\subsubsection{Suspension injunction and formal investigation procedure}

The recognition and enforcement of ICSID awards is provided for in Articles 53 through 55 of the Convention demonstrate a desire to eliminate review of awards by national courts e.g., ICSID Convention Art. 53 (awards "shall be binding on the parties and shall not be subject to any appeal or to any other remedy except those provided for in this Convention."). Nevertheless, ICSID awards must still be brought to national courts for recognition and enforcement should the losing party refuse to comply with their terms.

The Claimants started the Award enforcement in Romania and on March 24, 2014, the Bucharest Tribunal allowed the execution of the Award considering that the Award is a directly enforceable act, on the basis of Article 54 of ICSID and must be treated as a final domestic judgment excluding thus the procedure to recognize the award on the basis of the Romanian domestic law. On 30 March 2014 an executor started the enforcement procedure of the Award by setting the Romanian Ministry of Finance a deadline of 6 months to pay to the four claimants $80 \%$ of the award plus the interests and other costs. The enforcement procedure was initially temporarily suspended but was later reversed by the appeal court so Romania had no choice but to comply with its own domestic laws and start paying to the Micula brothers.

The EU Commission issued a suspension injunction on May 26, 2014 against Romania as a reaction to Romania starting the partially implementation of the award. This prevented the Member State from complying with the ICSID award until further determinations by the Commission were made. The Commission obliged Romania to suspend any action which may lead to the implementation or execution of the part of the Award that had not yet been paid, as that would constitute payment of unlawful State aid, until the Commission has taken a final decision on the compatibility of that State aid with the internal market.

The Commission soon initiated a formal investigation procedure pursuant to Article 108(2) of the TFEU in respect of the partial implementation of the Award by Romania that took place in early 2014 as well as in respect of any further implementation or execution of the Award. As far as partial implementation is concerned, Romania has cancelled outstanding tax debts of European Food SA against payables by Romania. ${ }^{42}$

The European Commission, in its decision on initiating the formal investigation procedure against Romania, has taken the position that enforcement of an arbitral award aiming to reinstate the status quo ante with regard to an EU decision declaring aid illegal and ordering such aid to be recovered is illegal. This was based on the fact that the initial state aid followed by the enforcement of the grant of state aid through arbitration and an enforcement of the award are single action (process). The European Commission argued that the initial state aid decision was illegal under EU law; the intra-EU BIT is illegal and is no longer valid and therefore, the effects of the illegal state aid enforced through an illegal mechanism contravening the EU State aid regime are contrary to EU law. ${ }^{43}$ The European Commission referred to its own decision and the decision of the European Court in support

42 Romania Implementation of Arbitral award Micula v Romania of 11 December 2013, European Commission Communication, paragraph 71, October 12014.

${ }^{43}$ Bruxelles, 01.10.2014 C(2014) 6848 final State aid SA.38517(2014/C) (ex 2014/NN) Romania Implementation of Arbitral award Micula v Romania 11 December 2013 at $<\mathrm{http}: / /$ ec. europa.eu/competition/state_aid/cases/254586/254586_1595781_31_11.pdf $>$ accessed 23 May 2016. 
of the first point. ${ }^{44}$ The second point refers to the response of Commissioner De Gucht to a Parliamentary oral Question in 2013, when he stated, "the Commission agrees that bilateral and investment treaties (BITS) between EU Member States do not comply with EU law." ${ }^{45}$ And is not a new argument. The European Commission and some Member States have already successfully argued this point in arbitrations.

In another companion case, Eastern Sugar, ${ }^{46}$ the Czech Republic, supported by the European Commission as amicus curiae, took the position that this BIT was automatically terminated following its accession to the EU and Dutch investments in its territory have since been governed exclusively under EU law. The arbitral tribunals in the Eastern Sugar case answered this question by rejecting the argument that the opinion of the European Commission is neither biding nor persuasive or clear for the tribunal. ${ }^{47}$ Moreover, the arbitral tribunal added that neither the European Agreement nor the Accession Treaty, nor the BIT itself provided expressly that the BIT would be terminated. ${ }^{48}$ Finally, the arbitral tribunal held that it was not bound by the opinion of the European Commission.

This matter was debated in greater depth in the Eureko $v$ Slovakia case ${ }^{49}$ and was decided in favour of the investors. Based on these awards, Canet and Doremus ${ }^{50}$ take the view that "the general inapplicability question....[is]...answered" and "remains the question of the inapplicability of specific provisions of Intra-EU bilateral Investment." Based on the aforementioned, the reference by the Commission to an answer by the former Commissioner to a Parliamentary question does not seem to be a particularly strong argument.

Regarding the final point, the Commission, in Micula, had switched to a variant of the effects principle and referenced the Lucchini case, where the Court held that a national court was prevented from applying national law if the application of that law would in effect "frustrate the application of Community law in so far as it would make it impossible to recover State aid that was granted in breach of Community law." ${ }^{51}$ In this context, the European Commission seems to argue that an intra-EU BIT is similar to a domestic law norm and, therefore, it is considered that the principle to apply is that "where giving effect to an intra-EU BIT by a Member State would frustrate the application of Union law, that

44 In the Micula case, as a condition of its accession to the EU, Romania repealed the tax incentives granted to the Micula brothers in 2004 because the EU considered such incentives impermissible state aid. In the Hungarian electricity cases (Electrabel, AES, EDFI) there was an EU Commission decision declaring the long term power purchase agreements as illegal under the EU rules.

45 Question O-000043/2013/rev.1 in debate of the plenary of 22 May 2013.

46 Eastern Sugar B.V. (Netherlands) v. The Czech Republic, SCC Case No. 088/2004.

47 See the EEC's letter to the tribunal in para 115 of Eastern Sugar B.V. (Netherlands) v. The Czech Republic, SCC Case No. 088/2004, 125.

48 Eastern Sugar B.V. (Netherlands) v. The Czech Republic, SCC Case No. 088/2004, 121 and 122.

49 PCA Case No. 2008-13 in the matter of an arbitration before a tribunal constituted in accordance with the agreement on encouragement and reciprocal protection of investments between the Kingdom of The Netherlands and The Czech and Slovak Federal Republic, signed on 29 April 1991, entered into force on 1 October 1992 between EUREKO B.V. ("Claimant") and the Slovak Republic award on jurisdiction, arbitrability and suspension 26 October 2010.

50 Canet (2013).

51 Judgment of 18.7.2007. Case C-119/05 Judgment of The Court (Grand Chamber) 18 July 2007, 23. 
Member State must uphold Union law." In other words, Member States must uphold Union law over an international agreement.

Hence, based on various points made by the Commission, it is indicative that the Commission took the view that a State aid related arbitral award, based on an intra-EU BIT is not applicable (enforceable) in the EU as it is itself state aid (attributable to the EU member state) and its effects would frustrate the application of EU law.

Specifically, the Commission cited Article 14 of Council Regulation No. 659/1999 which "provides that all unlawful aid may be recovered from the recipient." 52 For Romania's partial implementation of an award constituting state aid to be lawful, the aid must have "been granted in compliance with the procedure laid down in Article 108(3) of the TFEU." 53

\subsubsection{The EU Commission's recovery decision}

The Commission, after forming the belief that the award constituted unlawful state aid, ordered Romania to recover any and all amounts paid in accordance with the ICSID award to the Micula brothers or to any one of the entities constituting the single economic unit ${ }^{54}$ benefiting from that aid in further implementation of the arbitral award of 11 December 2013 that the Commission has not been made aware of or that is paid out after the date of this Decision. ${ }^{55}$ Romania must also ensure that no further payments of the aid shall be effected with effect from the date of adoption of the recovery decision.

\subsubsection{Claimants' reaction to the recovery decision}

The Micula brothers reacted by taking an action to annul the above decision ordering Romania to suspend any action which may lead to the execution or implementation of the award of 11 December 2013. ${ }^{56}$ According to the Micula brothers, "the Commission's decision fails to acknowledge that Romania is obligated by international law to execute the ICSID award without delay and that Romania's international law obligations take primacy over EU law" and also that the decision "infringes Article 351(1) TFEU and Article 4(3) TEU, which recognize and protect Romania's obligations under the ICSID Convention and under the [BIT]. ${ }^{57}$ The Micula brothers argued that EU law is not applicable to the case and the Commission lacks the competence to issue a decision as it fails to acknowledge that

52 Judgment of 18.7.2007, 74.

53 The "Final Decision" of the Commission declaring any payment under the Award a violation of European state aid laws, and ordered Petitioners to return any portion of the award Romania had already paid them. Petitioners have appealed the Suspension Injunction to the General Court of the European Union was issued on March 302015.

${ }^{54}$ According to the recovery decision, all entities concerned where the Micula brothers have majority shareholding, incl. Viorel Micula, Ioan Micula, S.C. European Food SA, S.C. Starmill S.R.L., S.C. Multipack, European Drinks SA, Rieni Drinks SA, Scandic Distilleries SA, Transilvania General Import-Export S.R.L., and West Leasing S.R.L shall be jointly liable to repay the State aid received by any one of them.

55 Commission decision (EU) 2015/1470 of 30 March 2015 on State aid SA.38517 (2014/C) (ex 2014/NN) implemented by Romania - Arbitral award Micula v Romania of 11 December 2013 (notified under document C(2015) 2112).

56 Case T-646/14: Action brought on 2 September 2014 - Micula v Commission OJ C 439, 8.12.2014, 29-30.

57 Action brought on 2 September 2014 - Micula v Commission, Case T-646/14, O.J. (C439/30). 
Romania is obligated by international law to execute the ICSID award without delay and that Romania's international law obligations take primacy over EU law. They also claimed that the Commission's decision infringes Article 351(1) TFEU and Article 4(3) TEU, which recognize and protect Romania's obligations under the ICSID Convention and under the Sweden-Romania BIT. The brothers also claimed that the Commission erred in law by wrongly categorizing the execution of the ICSID award as a new State aid measure and violated the applicants' legitimate expectations.

The issue is that the alleged infringement of Article 351 of the TFEU is not quite as clear-cut as the brothers seem to suggest and the Commission has stated that this particular provision does not apply, since the BIT in question concerns two Member States and not a Member State and a third country. ${ }^{58}$ However, the Micula brothers and the other applicants informed the Court that they wished to discontinue proceedings by a letter lodged at the Court Registry on 2 December 2015. The case was discontinued with an Order of the President of the General Court dated February 29, 2016 and the matter has been removed from the registry. ${ }^{59}$

\subsection{The Micula dispute in third countries}

Unfortunately for the Commission, the Micula brothers decided to take advantage of the delocalized nature of ICSID judgment enforcement and proceeded to the enforcement of the ICSID award in a third country such as the US District of Columbia. The United States is party to the ICSID Convention and has implemented its obligations under the Convention into the U.S. Code by providing that U.S. courts must recognize every arbitral award rendered pursuant to the ICSID Convention as if it were a "final judgment of a court in [the United States]."

The ICSID Convention does not require any particular procedure for recognition or enforcement of an ICSID award by the courts of each Contracting State. Congress implemented the ICSID Convention via 22 U.S.C. $§ 1650$ a. This enabling statute provides that "pecuniary obligations imposed by [...] an [ICSID] award shall be enforced and shall be given the same full faith and credit as if the award were a final judgment of a court of general jurisdiction of one of the several States." 60 This is in line with Article 54 of the ICSID Convention which allows Contracting States with federal constitutions to treat ICSID awards as if they were final judgments of a court in a constituent state. Importantly, the statute only expressly mentions enforcement and not recognition.

Notwithstanding this mandate, the procedures federal courts may utilize to implement ICSID awards in the United States remain unclear especially as to whether expedited (ex parte) procedures may be used to recognize an ICSID award or the foreign states (debtors) were entitled to advance notice and an opportunity to be heard prior to recognition of the award.

The New York courts have been consistently clear that ICSID award creditors may take advantage of expedited (ex parte) procedures in seeking recognition of an ICSID

58 EC Communication, paragraph 51.

59 See at http://curia.europa.eu/juris/document/document.jsf;jsessionid=9ea7d2dc30d57d9ce9b1 7ca049a79df4c3bbb12 adc5e.e34KaxiLc3qMb40Rch0SaxuSbxv0?text=\&docid=174864\&pageIndex $=0 \&$ doclang $=$ en $\&$ mode $=1$ st $\&$ dir $=\& o c c=$ first $\&$ part $=1 \&$ cid $=116955>$ accessed 23 May 2016.

6022 U.S.C. $\S 1650 \mathrm{a}(\mathrm{a})$. 
award $^{61}$ but the New York courts also found that they could not issue writs of execution, as sovereign assets were protected under the Foreign Sovereign Immunities Act (FSIA). ${ }^{62}$ In Mobil Cerro Negro, Ltd. v. Bolivarian Republic of Venezuela ${ }^{63}$ in December 2014, the New York District Court declared that the use of ex parte recognition procedures was proper to confirm a $\$ 1.6$ billion ICSID award against Venezuela in the state of New York. Venezuela argued, in conjunction with other arguments, that the FSIA superseded any procedures for recognizing ICSID awards. The Court noted that the "FSIA repeatedly uses terms that presuppose litigation over a contested issue," suggesting that Congress did not contemplate that the FSIA would apply in proceedings where there were no substantive issues being decided and found that Section 1650a's use of the phrase "full faith and credit" likened the recognition of an ICSID award to the recognition of a judgment in another state of the US and a procedure that does not require personal jurisdiction over the judgment debtor in the recognizing court. ${ }^{64}$ In Miminco, LLC v. Democratic Republic of the Congo ${ }^{65}$ the D.C. District Court determined that "ex parte proceedings suffice for recognition of ICSID arbitral awards".

In May 2015, Petitioner Viorel Micula filed a petition with the D.C. District Court for ex parte recognition of a $\$ 116$ million ICSID award rendered against Romania. ${ }^{66} \mathrm{He}$ cited the above line of cases dealing with ex parte recognition in the Southern District of New York. The Court rejected Micula's petition principally upon a textual analysis of $\S 1650 \mathrm{a}$. The D.C. District Court rejected any distinction between recognition and emphasized that the enabling statute refers only to enforcement of awards, and not to recognition. The Court acknowledged its obligation to enforce an ICSID award in the same manner as a state court judgment but noted that the only proper means of recognizing a state court judgment in federal court is through an action on the judgment as a debt, a plenary proceeding.

Other petitioners sought recognition of the award in the New York District Court a few days after the D.C. District Court denied Viorel Micula's application to recognize the ICSID award ${ }^{67}$ and the application was granted. Romania sought to vacate the judgment entered by the Court, asserting that it violated the FSIA and arguing that the Court should abstain from exercising jurisdiction on the basis of international comity, the act of state doctrine and the foreign sovereign compulsion doctrine. The judge to whom Romania's motion was assigned, rejected each of these arguments. On the last point, the Court rejected Romania's argument that because the award involved only European parties, the Court should defer to

${ }^{61}$ Liberian Eastern Timber Corp. v. Republic of Liberia, 650 F. Supp. 73 (S.D.N.Y. 1986); Grenada v. Grynberg, No. 11 Misc. 45 (S.D.N.Y. Apr. 29, 2011); Enron Corp. \& Ponderosa Assets L.P. v. Argentine Republic, No. M-82 (S.D.N.Y. Nov. 20, 2007); Sempra Energy Int'1 v. Argentine Republic, No. M-82 (S.D.N.Y. Nov. 14, 2007); Siag v. Arab Republic of Egypt, No. M-82 (PKC), 2009 WL 1834562 (S.D.N.Y. June 19, 2009), Mobil Cerro Negro Ltd. v. Bolivarian Republic of Venezuela, No. 14 CIV. 8163 PAE, 2015 WL 631409 (S.D.N.Y. Feb. 13, 2015)

${ }^{62}$ Liberian Eastern Timber Corp. v. Republic of Liberia, 650 F. Supp. 73 (S.D.N.Y. 1986), $76-78$.

63 Mobil Cerro Negro Ltd. v. Bolivarian Republic of Venezuela, No. 14 CIV. 8163 PAE, 2015 WL 631409 (S.D.N.Y. Feb. 13, 2015)

64 Mobil Cerro Negro Ltd. v. Bolivarian Republic of Venezuela, 21.

65 No. CV 14-01987 (RC), 2015 WL 1061555 (D.D.C. Feb. 9, 2015)

66 1:14-cv-00600 (APM), U.S. Dist. LEXIS 64461 (D.D.C. May 18, 2015)

67 Micula v. Government of Romania ("Micula II"), No. 15 MISC. 107, 2015 WL 4643180, at *1 (S.D.N.Y. Aug. 5, 2015) 
the judgment of either the EU Court of Justice or the national courts of the EU Member States. It found that a stay of the enforcement proceedings "would undermine the ICSID Convention's expansive spirit on which many American investors rely when they seek to confirm awards in the national courts of the Convention's other member states."

\section{CONCLUSIONS}

It appears that Romania and the European Commission are in losing international battle with the Swedish-Romanian Micula brothers. The EU may be able to prevent execution and enforcement of the award within its boundaries but it may not be able to block execution and enforcement beyond its borders. As a consequence, Romania may have to pay a substantial amount of money to the Micula brothers and their holdings based on foreign court decisions implementing and enforcing the arbitral award. The Micula case may be a climax to the disputes based on intra-EU BITs. While the circularity argument put forward by the European Commission in cases based on intra-EU BITs does not seem to work in the Micula case despite having worked in some earlier cases.

The Commission must deal with concurrent pre-existing cases on a piecemeal basis while, in order to avoid future cases, it must somehow terminate all intra-EU BITs.

\section{LITERATURE}

Canet, A., Doremus, T., 'Problems and challenges of intra-EU investment treaties' at $<$ https://www. academia.edu/8735310/Problems_and_challenges_of_Intra-EU_investment_treaties_Intra-EU_ BITS $>$ accessed 29 May 2016.

González-Bueno, C., Lozano, L., 'More Than a Friend of the Court: The Evolving Role of the European Commission in Investor-State Arbitration' at <http://kluwerarbitrationblog.com/blog/ 2015/01/26/more-than-a-friend-of-the-court-the-evolving-role-of-the-european-commission-ininvestor-state-arbitration/> accessed 29 May 2016.

Olivet, C., A test for European solidarity; The case of Intra- EU Bilateral Investment Treaties (Amsterdam 2013)

Tietje, Ch., Wackernagel, C., 'Outlawing compliance? The enforcement of intra-EU investment awards and EU state aid law’ (2014) 41 Policy Papers on Transnational Economic Law 111-157. 